\title{
Electrochemical and Sulfide Stress Corrosion Cracking Behaviors of Tubing Steels in a $\mathrm{H}_{2} \mathrm{~S} / \mathrm{CO}_{2}$ Annular Environment
}

\author{
Z.Y. Liu, X.Z. Wang, R.K. Liu, C.W. Du, and X.G. Li
}

\author{
(Submitted September 17, 2013; in revised form December 12, 2013; published online February 27, 2014)
}

\begin{abstract}
The electrochemical and sulfide stress corrosion cracking (SSCC) behaviors of $13 \mathrm{Cr}$ stainless steel and P110 steel were investigated in a simulated acidic annular environment with low-temperature and high-pressure $\mathrm{H}_{2} \mathrm{~S} / \mathrm{CO}_{2}$ using electrochemical methods, U-bend immersion tests, and scanning electron microscopy. In the solution containing high pressure $\mathrm{CO}_{2}, 13 \mathrm{Cr}$, and $\mathrm{P110}$ steels exhibited general corrosion and severe pitting, respectively. Compared with sweet corrosion, additional $\mathrm{H}_{2} \mathrm{~S}$ in the solution enhanced the corrosion of $13 \mathrm{Cr}$ steel but inhibited the corrosion of $\mathrm{P110}$ steel. By contrast, in a solution containing $4 \mathrm{MPa} \mathrm{CO}_{2}$ and different $P_{\mathrm{H}_{2} \mathrm{~S}}(0-0.3 \mathrm{MPa})$, the susceptibility of both $13 \mathrm{Cr}$ stainless steel and P110 steel toward SSCC was significantly promoted by increases in $\mathrm{H}_{2} \mathrm{~S}$ partial pressure. The $13 \mathrm{Cr}$ stainless steel exhibited higher susceptibility toward SSCC than P110 steel under a $\mathrm{H}_{2} \mathrm{~S} / \mathrm{CO}_{2}$ environment but lower susceptibility under a pure $\mathrm{CO}_{2}$ environment.
\end{abstract}

Keywords annular environment, $\mathrm{H}_{2} \mathrm{~S} / \mathrm{CO}_{2}$ corrosion, SSCC, tubing steel

\section{Introduction}

During oil and gas exploitation, complex work conditions cause serious corrosion in tubular steel in sour oil and gas wells. Considerable effort has been exerted to study the effects of environmental aspects, material characteristics, and corrosion scales on sulfide stress corrosion cracking (SSCC) in oil and gas wells, where $\mathrm{CO}_{2}$ and $\mathrm{H}_{2} \mathrm{~S}$ coexist (Ref 1-6). However, most reports focus on the internal corrosion (Ref 7,8) of tubular and pipeline steels during the exploitation and transportation of oil and gas, and limited attention has been directed toward studies on $\mathrm{H}_{2} \mathrm{~S} / \mathrm{CO}_{2}$ corrosion under an annular environment (Ref 9-12) between tubing steel and casing steel. Several tubing steel failure accidents recently occurred in some oil fields in China, and investigations have been conducted to determine the most probable causes of these failures. Results showed that the chemical composition, metallographic structure, and mechanical properties of the tubing steels are in accordance with the relevant technical requirements of API Spec 5CT standards (Ref 13). Based on analyses of macroscopic fracture characteristics, fractographs, microscopic cracks, and x-ray diffractograms of surface films and deposits at the fracture position, SSCC induced by cracks originating outside the tubing steel appear to be responsible for the accidents.

SSCC failures occurring under an annular environment between tubing and casing steels are a new type of corrosion

Z.Y. Liu, X.Z. Wang, R.K. Liu, C.W. Du and X.G. Li, Corrosion \& Protection Center, University of Science \& Technology Beijing, Beijing, China. Contact e-mails: wxzupc07043318ustb@gmail.com and lixiaogang99@263.net. phenomenon in $\mathrm{CO}_{2}$ injection wells. Our investigation on the annular medium showed the complexity of this annular environment with low temperature $\left(0-30^{\circ} \mathrm{C}\right)$, high-pressure $\mathrm{H}_{2} \mathrm{~S} / \mathrm{CO}_{2}$, and low $\mathrm{pH}(\sim 4)$. Compared with corrosion under a high-temperature/high-pressure environment in down-hole wells, corrosion under a low-temperature/high-pressure environment promotes higher susceptibility to stress corrosion cracking (SCC). The design of control methods and selection of suitable materials are difficult because of the lack of data on tubing steel corrosion under an annular environment, especially under high partial pressures of $\mathrm{H}_{2} \mathrm{~S}\left(P_{\mathrm{H}_{2} \mathrm{~S}}=0.05\right.$ to $\left.0.3 \mathrm{MPa}\right)$. Thus, studies on $\mathrm{H}_{2} \mathrm{~S} / \mathrm{CO}_{2}$ corrosion and SSCC of tubular steels under acidic annular environments are of great importance.

Two types of steels, namely, $13 \mathrm{Cr}$ stainless steel and P110 steel, both of which are widely used as tubing materials for oil and gas wells (Ref 14, 15), were chosen as experimental materials in this study, and the corrosion behaviors of these steels under a specific annular environment were compared. The results of this study provide support for the selection of materials used in oil and gas wells.

This study aims to compare the electrochemical corrosion and SSCC behaviors of $13 \mathrm{Cr}$ and $\mathrm{P} 110$ steels under an acidic, low-temperature, high-pressure $\mathrm{H}_{2} \mathrm{~S} / \mathrm{CO}_{2}$ annular environment. This study also evaluates the effect of $P_{\mathrm{H}_{2} \mathrm{~S}}$ on the corrosion behavior of tubing steels using static load U-bend immersion tests, electrochemical measurements, and scanning electron microscopy (SEM).

\section{Experimental}

\subsection{Materials and Test Solution}

$13 \mathrm{Cr}$ and P110 steels, the chemical compositions and mechanical properties of which are shown in Table 1, were 
used in this experiment. Based on a survey on the chemical composition of the solution medium in a real tubing annular environment, the test solution was composed of $\mathrm{NaHCO}_{3}$ (2.71 g/L), $\mathrm{NaCl}(6.15 \mathrm{~g} / \mathrm{L})$, and $\mathrm{Na}_{2} \mathrm{SO}_{4}(0.33 \mathrm{~g} / \mathrm{L})$ to simulate actual working conditions. The solution $\mathrm{pH}$ was then adjusted to 4 with $5 \%$ acetic acid. Given that an inhibitor is widely used in actual operational activities to control the corrosion of steels (Ref 16, 17), a 1000 ppm inhibitor (a commercial imidazolinebased product) was added to the solution under several test conditions to insure that test results are as close to real conditions as possible.

\subsection{Electrochemical Measurements}

All the samples used for electrochemical tests were coated with epoxy, and an exposure area of $10 \times 10 \mathrm{~mm}^{2}$ served as the working surface. The working surface was ground using 1200 grit sandpaper, degreased with acetone, and rinsed with deionized water. High-pressure tests were performed using an autoclave with a capacity of $1 \mathrm{~L}$. After the specimens and test solution were placed in the autoclave, the solution was deaerated by purging nitrogen for $1 \mathrm{~h}$. The autoclave was then pressured with $\mathrm{H}_{2} \mathrm{~S}$ to the required levels, which ranged from 0 to $0.3 \mathrm{MPa}$. $\mathrm{CO}_{2}$ and $\mathrm{N}_{2}$ were pressured to 4 and $9 \mathrm{MPa}$, respectively. The test conditions are shown in Table 2.

An EG\&G M2273 electrochemical test system was used for electrochemical measurements. A three-electrode test cell was used with a platinum plate as the counter electrode, a $\mathrm{Ag} / \mathrm{AgCl}$ electrode as the reference electrode, and the steel specimen as the working electrode. Potentiodynamic polarization curves were obtained by changing the electrode potential automatically from the cathodic branch to the anodic branch at a scan rate of $0.5 \mathrm{mV} / \mathrm{s}$. Electrochemical impedance spectroscopy (EIS) was measured at open circuit potential with a sinusoidal potential excitation of $10 \mathrm{mV}$ amplitude in the frequency range of $100 \mathrm{kHz}$ to $10 \mathrm{mHz}$. The impedance data were fitted with ZsimpWin software using equivalent circuits. Experiments for each $\mathrm{H}_{2} \mathrm{~S}$ concentration were conducted at least thrice to insure that the results were reproducible and reliable.

\subsection{Static Load U-bend Immersion Tests}

U-bend immersion tests are useful in studying the SCC mechanism and propagation mode of materials under static load and static strain in a specific environment (Ref 18). Therefore, this study used U-bend immersion tests to investigate the effect of $\mathrm{H}_{2} \mathrm{~S}$ on SSCC susceptibility under a high-pressure $\mathrm{CO}_{2} / \mathrm{H}_{2} \mathrm{~S}$ environment. Immersion tests were performed in a highpressure autoclave with a capacity of $3 \mathrm{~L}$. The working conditions (such as the test solution, order for pressured gases, and specific partial pressure parameters of the gases) for static load U-bend immersion tests were identical to those used for the electrochemical test. Three parallel specimens for each type of material were placed in the test solution for every test, which lasted for $720 \mathrm{~h}$ at room temperature.

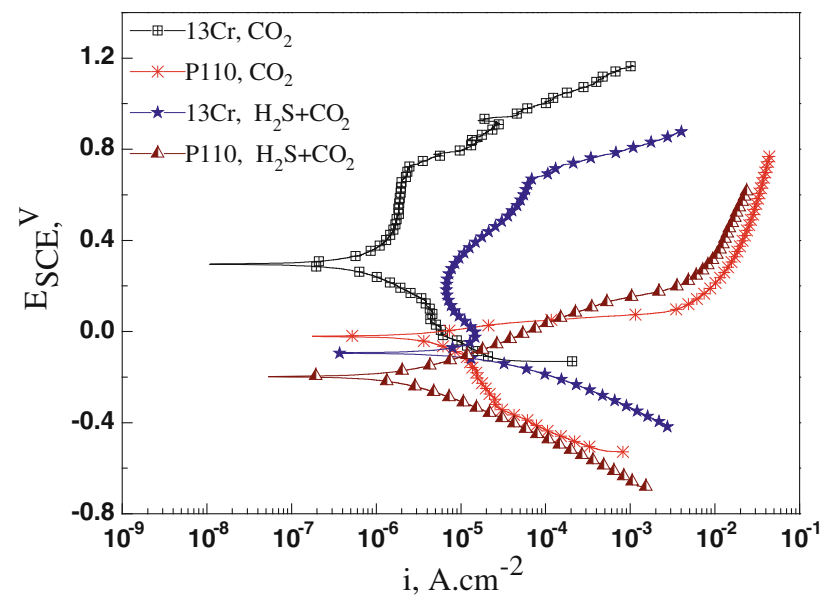

Fig. 1 Polarization curves of $13 \mathrm{Cr}$ and $\mathrm{P} 110$ with/without $\mathrm{H}_{2} \mathrm{~S}$

Table 1 Chemical components and mechanical properties of the steel samples (mass fraction, \%)

\begin{tabular}{|c|c|c|c|c|c|c|c|c|c|c|}
\hline \multirow[b]{2}{*}{ Materials } & \multicolumn{8}{|c|}{ Elements } & \multicolumn{2}{|c|}{$\begin{array}{c}\text { Mechanical } \\
\text { properties }\end{array}$} \\
\hline & C & $\mathbf{S i}$ & Mn & $\mathbf{P}$ & $\mathbf{S}$ & $\mathrm{Cr}$ & Mo & $\mathbf{N i}$ & $\sigma_{\mathbf{y}}$ & $\sigma_{b}$ \\
\hline $13 \mathrm{Cr}$ & 0.18 & 0.03 & 0.48 & 0.02 & 0.004 & 12.94 & 0.015 & 0.1 & 758 & 862 \\
\hline P110 & 0.27 & 0.22 & 1.69 & 0.0095 & 0.003 & 0.033 & 0.018 & 0.029 & 814 & 912 \\
\hline
\end{tabular}

Table 2 Test conditions for electrochemical measurements and immersion tests

\begin{tabular}{|c|c|c|c|c|c|c|c|c|}
\hline \multirow[b]{2}{*}{ Materials } & \multirow[b]{2}{*}{ Temperature,${ }^{\circ} \mathrm{C}$} & \multirow[b]{2}{*}{$\mathbf{p H}$} & \multirow[b]{2}{*}{$\mathrm{PCO}_{2}, \mathrm{MPa}$} & \multirow[b]{2}{*}{ Total pressure, MPa } & \multicolumn{2}{|c|}{ Electrochemical tests } & \multicolumn{2}{|c|}{ Immersion tests } \\
\hline & & & & & $P_{\mathrm{H}_{2} \mathrm{~S}}$, MPa & Inhibitor, ppm & $P_{\mathrm{H}_{2} \mathrm{~S}}, \mathrm{MPa}$ & Inhibitor, ppm \\
\hline \multirow[t]{5}{*}{$13 \mathrm{Cr}$ P110 } & 25 & 4.0 & 4.0 & 9.0 & 0 & 1000 & 0 & 0,1000 \\
\hline & & & & & 0.05 & 1000 & 0.1 & 1000 \\
\hline & & & & & 0.1 & 1000 & 0.2 & 0,1000 \\
\hline & & & & & 0.2 & 1000 & 0.3 & 1000 \\
\hline & & & & & 0.3 & 1000 & $\ldots$ & $\ldots$ \\
\hline
\end{tabular}




\subsection{Surface Analysis}

After the corrosion tests, the immersed U-bend specimens used for surfacing analysis were removed and rinsed with deionized water. A wire cutter was used to cut the top parts of two parallel specimens. A heavy stress was applied to these parts, which were then immersed in descaling solution $(500 \mathrm{~mL}$ of $\mathrm{HCl}+500 \mathrm{~mL}$ of $\mathrm{H}_{2} \mathrm{O}+3.5 \mathrm{~g}$ of $\left.\left(\mathrm{CH}_{2}\right)_{6} \mathrm{~N}_{4}\right)$ in an ultrasonic container for $3 \mathrm{~min}$. Another specimen was retained for backup. The specimens were then degreased with acetone and

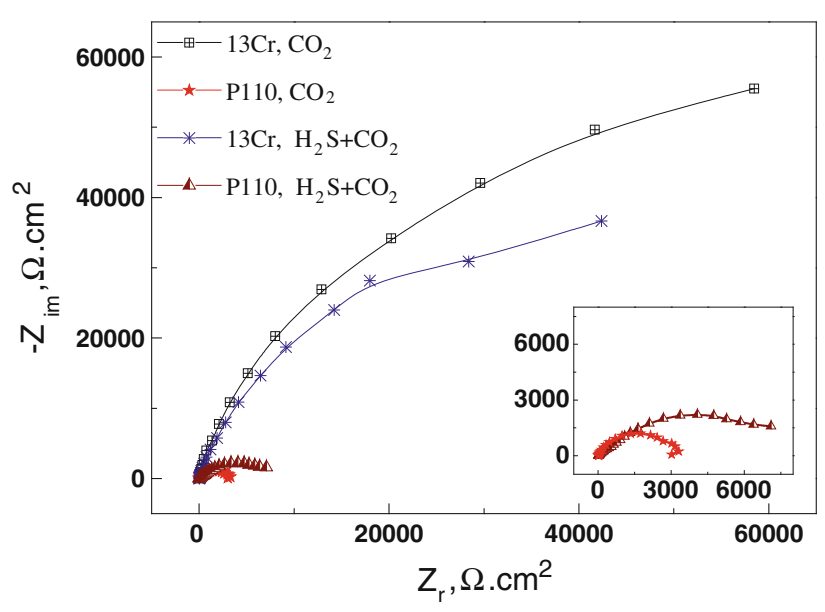

Fig. 2 EIS curves of $13 \mathrm{Cr}$ and $\mathrm{P} 110$ with/without $\mathrm{H}_{2} \mathrm{~S}$
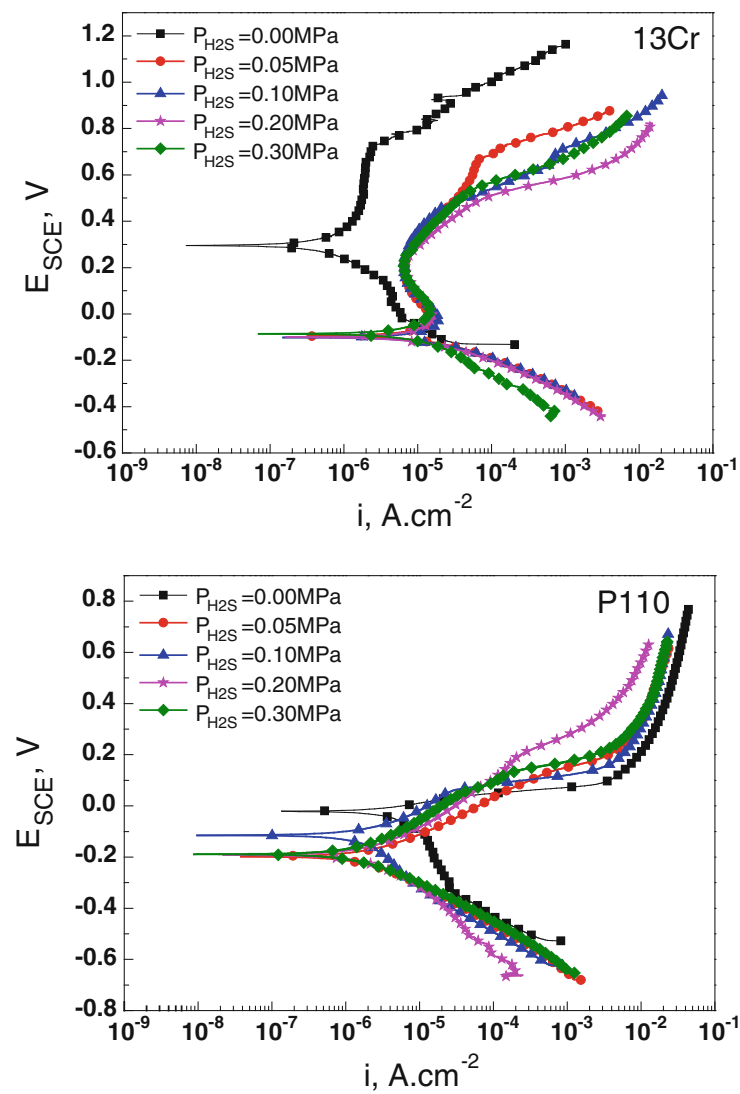

dried with cool air, and their surface morphologies were observed by SEM.

\section{Results}

\subsection{Effect of $\mathrm{H}_{2} \mathrm{~S}$ on the Electrochemical Behavior of $13 \mathrm{Cr}$ and P110 Steels}

Figure 1 shows the polarization curves of $13 \mathrm{Cr}$ stainless steel and P110 steel in solutions containing $4 \mathrm{MPa} \mathrm{CO}_{2}$ with/ without $0.05 \mathrm{MPa} \mathrm{H}_{2} \mathrm{~S}$. Two curves for $13 \mathrm{Cr}$ stainless steel showed obvious passive characteristics; by contrast, the curves of P110 steel showed active dissolution characteristics. Compared with the $\mathrm{H}_{2} \mathrm{~S}$-free condition, addition of $0.05 \mathrm{MPa}_{2} \mathrm{~S}$ significantly increased the passive current density $\left(i_{\text {pass }}\right)$ of $13 \mathrm{Cr}$ stainless steel but slightly decreased the $i_{\text {corr }}$ of P110 steel. For $13 \mathrm{Cr}$ stainless steel, the increase in $i_{\text {pass }}$ implies that both anodic iron dissolution and cathode reduction were accelerated because of the presence of $\mathrm{H}_{2} \mathrm{~S}$. For P110 steel, the decrease in $i_{\text {corr }}$ demonstrates that the corrosion process was, to some extent, inhibited by the presence of $\mathrm{H}_{2} \mathrm{~S}$. Compared with sweet corrosion, the presence of $\mathrm{H}_{2} \mathrm{~S}$ moved the corrosion potentials strongly toward the negative direction in both $13 \mathrm{Cr}$ and $\mathrm{P} 110$ steels.

The EIS curves of $13 \mathrm{Cr}$ stainless steel and P110 steel measured at open-circuit potential mode in solutions containing $4 \mathrm{MPa} \mathrm{CO}_{2}$ with/without $0.05 \mathrm{MPa} \mathrm{H}_{2} \mathrm{~S}$ are shown in Fig. 2. The Nyquist plots exhibited characteristic capacitive
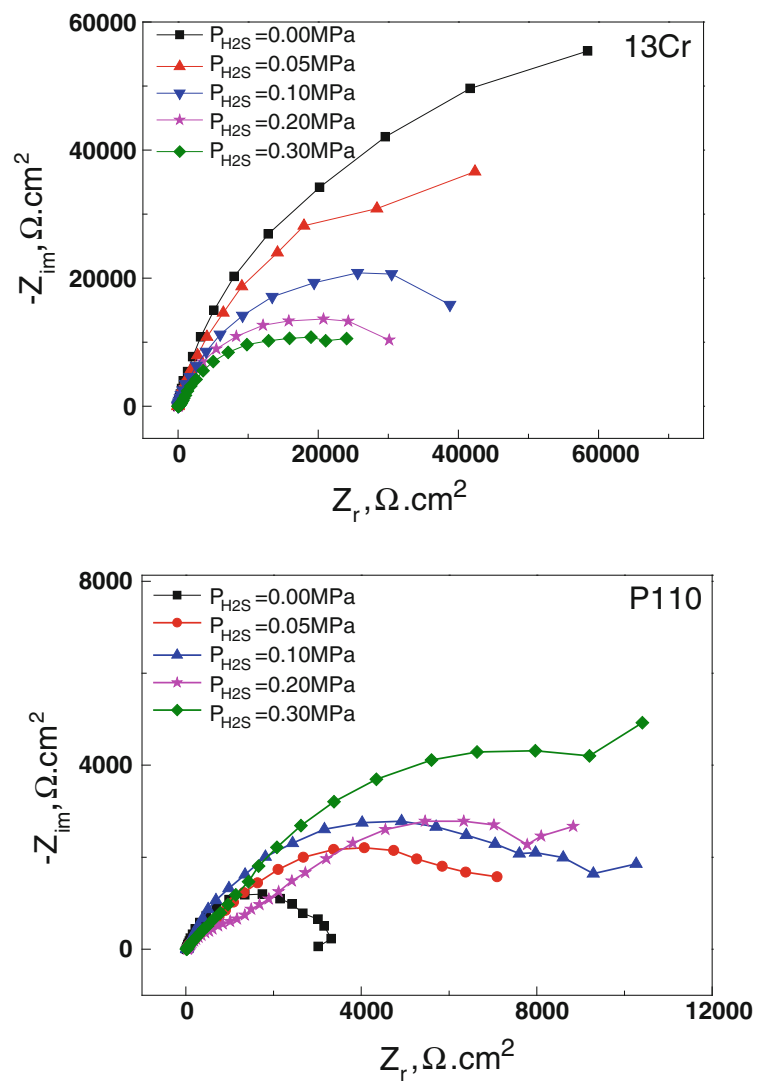

Fig. 3 Polarization and EIS curves of $13 \mathrm{Cr}$ and $\mathrm{P} 110$ under different $P_{\mathrm{H}_{2} \mathrm{~S}}$ 
semicircles, and the diameter of the capacitive semicircle of $13 \mathrm{Cr}$ stainless steel was significantly larger than that for P110 steel. Compared with the $\mathrm{H}_{2} \mathrm{~S}$-free condition, addition of $0.05 \mathrm{MPa} \mathrm{H}_{2} \mathrm{~S}$ slightly decreased the diameter of the capacitive semicircle of $13 \mathrm{Cr}$ stainless steel but significantly increased the diameter of the capacitive semicircle of P110 steel. This result demonstrates that the presence of $\mathrm{H}_{2} \mathrm{~S}$ degrades the corrosion resistance of $13 \mathrm{Cr}$ stainless steel but improves that of P110 steel under the test conditions. The results so far are consistent with the results obtained from the polarization curves. Moreover, the shape of the Nyquist plots (capacitive loop) of each steel did not change with/without $\mathrm{H}_{2} \mathrm{~S}$, which indicates the same mechanism for steel corrosion throughout the entire test.

\subsection{Effect of Different $\boldsymbol{P}_{\mathrm{H}_{2} \mathrm{~S}}$ on the Corrosion Behavior of $13 \mathrm{Cr}$ and P110 Steels}

Figure 3 shows the polarization and EIS curves of $13 \mathrm{Cr}$ and P110 steels under different $P_{\mathrm{H}_{2} \mathrm{~S}}$. An equivalent circuit shown in Fig. 4 was used to fit the EIS data to quantify the electrochemical parameters. In this equivalent circuit, $R_{\mathrm{s}}$ represents the solution resistance, $Q_{\mathrm{f}}$ represents the capacitance of the corrosion product film, $R_{\mathrm{f}}$ represents the resistance of the corrosion product film, $Q_{\mathrm{dl}}$ represents the double layer capacitance, and $R_{\mathrm{ct}}$ represents the charge transfer resistance. As both $R_{\mathrm{f}}$ and $R_{\mathrm{ct}}$ represent the resistances of the corrosion process of carbon steel, a parameter named polarization resistance, $R_{\mathrm{p}}$ $\left(R_{\mathrm{p}}=R_{\mathrm{f}}+R_{\mathrm{ct}}\right)$, was used to evaluate the corrosion rate of carbon steel in a $\mathrm{H}_{2} \mathrm{~S} / \mathrm{CO}_{2}$ environment (Ref 19).

Figure 5 shows the relationships of the EIS fitting results $R_{\mathrm{p}}$, the corrosion current density $i_{\text {corr }}$ of P110, and the passive current density $i_{\text {pass }}$ of $13 \mathrm{Cr}$ with different $\mathrm{H}_{2} \mathrm{~S}$ partial pressures. The parameters $i_{\text {pass }}\left(i_{\text {corr }}\right)$ and $1 / R_{\mathrm{p}}$ are in good agreement with each other. In Fig. 5(a), the $R_{\mathrm{p}}$ of $13 \mathrm{Cr}$ stainless steel without $\mathrm{H}_{2} \mathrm{~S}$ and $0.05 \mathrm{MPa} P_{\mathrm{H}_{2} \mathrm{~S}}$ exhibited significantly

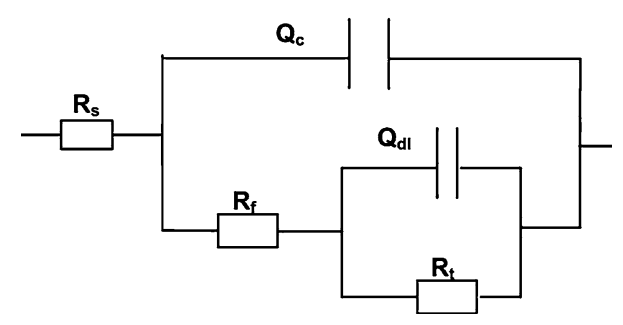

Fig. 4 Equivalent circuit for fitting EIS data higher values than those obtained at higher $\mathrm{H}_{2} \mathrm{~S}$ partial pressures $\left(0.1\right.$ to $\left.0.3 \mathrm{MPa} P_{\mathrm{H}_{2} \mathrm{~S}}\right)$, and the $i_{\text {pass }}$ increased greatly in the presence of $\mathrm{H}_{2} \mathrm{~S}$. However, $i_{\text {pass }}$ remained stable as the $\mathrm{H}_{2} \mathrm{~S}$ partial pressure increased from 0.05 to $0.3 \mathrm{MPa}$. In Fig. 5(b), the regularity of the change in $1 / R_{\mathrm{p}}$ of P110 steel was consistent with that of $i_{\text {corr }}$; both $1 / R_{\mathrm{p}}$ and $i_{\text {corr }}$ significantly decreased with increasing $\mathrm{H}_{2} \mathrm{~S}$ partial pressure. The lowest $R_{\mathrm{p}}$ and largest $i_{\text {corr }}$ both occurred during sweet corrosion, and the presence of $\mathrm{H}_{2} \mathrm{~S}$ significantly decreased the $i_{\text {corr }}$ of the steel.

After the high-pressure immersion tests, the U-bend specimens were subjected to surface analysis after the removal of corrosion scales. Figure 6 shows micrographs of the surfaces of $13 \mathrm{Cr}$ stainless steel. Uniform corrosion was observed during sweet corrosion, while cracks on the surface of the sample could be observed during sour corrosion. Figure 6(b-d) shows that the width and depth of the cracks on the surface of $13 \mathrm{Cr}$ steel increased with increasing partial pressure of $\mathrm{H}_{2} \mathrm{~S}$, which indicates that increases in $\mathrm{H}_{2} \mathrm{~S}$ enhance susceptibility toward SSCC. Moreover, the U-bend samples subjected to 0.2 and $0.3 \mathrm{MPa} \mathrm{H}_{2} \mathrm{~S}$ partial pressures were fractured (no failure specimen was observed at 0 and $0.1 \mathrm{MPa} \mathrm{H}_{2} \mathrm{~S}$ partial pressure). The fracture cross-sections of the specimens are shown in Fig. 6(e) and (f). SSCC cracks were initiated on the steel surface and continued to propagate until the ligament of the specimen could no longer bear the applied load.

Figure 7 shows the morphology of the surface of P110 tubing steel obtained under various $P_{\mathrm{H}_{2} \mathrm{~S}}$ after the removal of corrosion products. Corrosion pits with diameters of $\sim 25 \mu \mathrm{m}$ and small-sized cracks were observed without $\mathrm{H}_{2} \mathrm{~S}$. At $0.1 \mathrm{MPa}$ $P_{\mathrm{H}_{2} \mathrm{~S}}$, slight corrosion and a few small cracks were observed on the matrix. These generated cracks are related to hydrogen evolution during the cathodic process in the presence of $\mathrm{H}_{2} \mathrm{~S}$. Hydrogen atoms that penetrate into the substrate facilitate the nucleation of cracks. As the $\mathrm{H}_{2} \mathrm{~S}$ partial pressure increased to 0.2 and $0.3 \mathrm{MPa}$, the depth and number of cracks significantly increased, which indicates that the cathodic process was significantly accelerated and that hydrogen ingress into the matrix was enhanced.

\subsection{Effect of Corrosion Inhibitor on the Corrosion Behavior of $13 \mathrm{Cr}$ and P110 Steels}

Figure 8 shows the SEM morphology of U-bent specimens of $13 \mathrm{Cr}$ stainless steel and P110 steel obtained without corrosion inhibitor after the removal of corrosion products. In corrosive medium without inhibitor, the metal comes into direct contact with anions and subsequent dissolution of the matrix
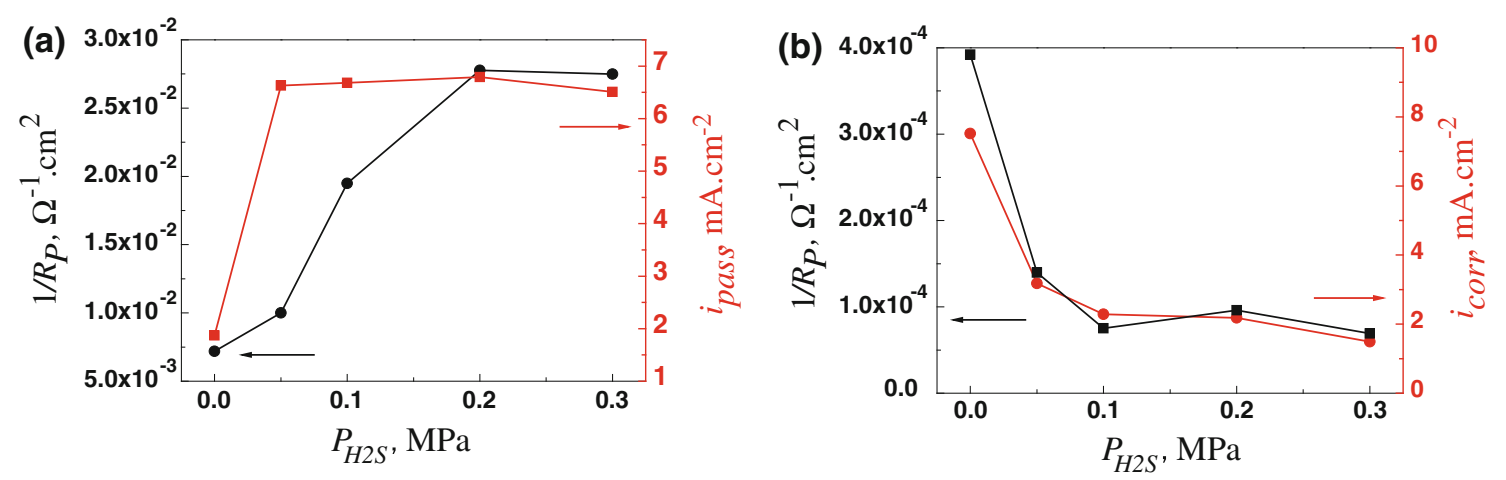

Fig. 5 Variation in $1 / R_{\mathrm{p}}$ and $i_{\text {pass }}\left(i_{\text {corr }}\right)$ with increasing $\mathrm{H}_{2} \mathrm{~S}$ partial pressures of (a) $13 \mathrm{Cr}$ and (b) P110 

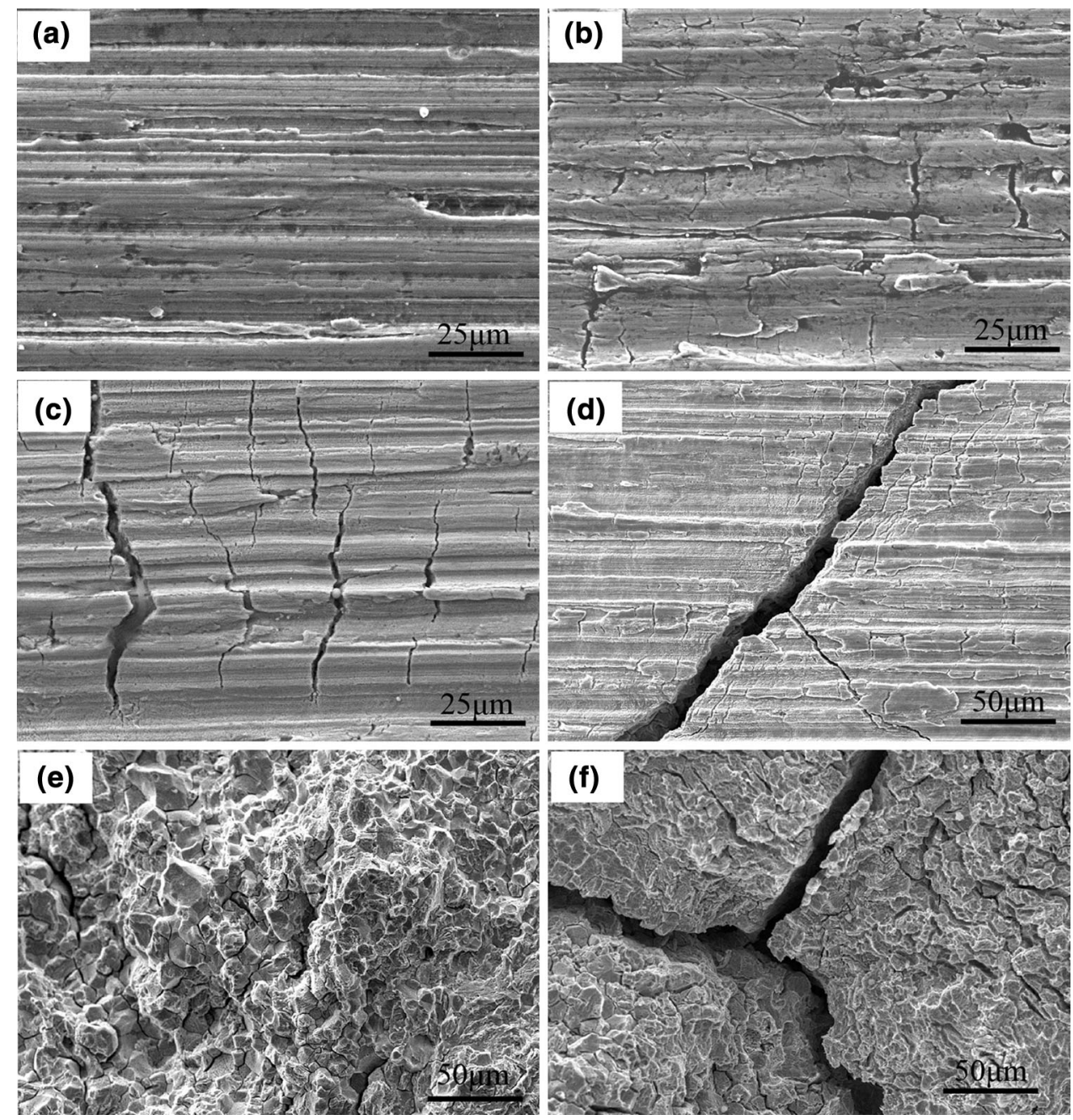

Fig. 6 SEM morphology of U-bend specimens of $13 \mathrm{Cr}$ stainless steel under various $\mathrm{H}_{2} \mathrm{~S}$ partial pressures of (a) $P_{\mathrm{H}_{2} \mathrm{~S}}=0 \mathrm{MPa}$, (b) $P_{\mathrm{H}_{2} \mathrm{~S}}=0.1 \mathrm{MPa}$, (c) $P_{\mathrm{H}_{2} \mathrm{~S}}=0.2 \mathrm{MPa}$, and (d) $P_{\mathrm{H}_{2} \mathrm{~S}}=0.3 \mathrm{MPa}$ and the fractography at (e) $P_{\mathrm{H}_{2} \mathrm{~S}}=0.2 \mathrm{MPa}$ and (f) $P_{\mathrm{H}_{2} \mathrm{~S}}=0.3 \mathrm{MPa}$. All of the test solutions contained $1000 \mathrm{ppm}$ corrosion inhibitor

occurs at the metal-solution interface. Therefore, severe corrosion occurs in metals in acidic solution without inhibitor. Upon addition of $1000 \mathrm{ppm}$ inhibitor to the test solution, inhibitors function by adsorption of ions or molecules onto metal surface. The inhibitor prevents direct contact between the matrix and the corrosive medium and can thus reduce the corrosion rate by decreasing the anodic and/or cathodic reaction (Ref 17). Thus, compared with that in the solution without inhibitor, the corrosion process decreased greatly in the solution with inhibitor, as shown in Figs. 6(a) and (c) and 7(a) and (c). These results indicate that the inhibitor decreases the corrosion rate of the matrix significantly.

\section{Discussion}

\subsection{Analysis of the Formation of the Annular Environment of $\mathrm{CO}_{2}$ Injection Wells}

$\mathrm{CO}_{2}$ oil displacement technology, a type of technology for enhanced oil recovery that requires the injection of $\mathrm{CO}_{2}$ into underground reservoirs, has attracted worldwide attention for its many advantages, which include low cost, non-toxicity, environmental protection, and good miscibility with crude oil (Ref 20, 21). In natural gas and oil wells, packers are used to insure that the exterior of the tubing steel and the interior of the casing steel do not touch the corrosion medium. However, some defects may exist in the tubular steel, and these defects could cause widespread leakage of production steel. Corrosion at defect sites during service worsens the leakage problem. In $\mathrm{CO}_{2}$ injection wells, the high pressure of $\mathrm{CO}_{2}$ injected into the underground natural gas reservoirs may result in the following:

(1) High pressure (4-20 MPa) at the wellhead;

(2) A relatively low-temperature $\left(0-30{ }^{\circ} \mathrm{C}\right)$ environment at a certain depth; and

(3) Partial $\mathrm{CO}_{2}$ leakage into the annular environment from defects of the tubular steel.

$\mathrm{CO}_{2}$ then dissociates into the annular environment protective liquid:

$\mathrm{CO}_{2}+\mathrm{H}_{2} \mathrm{O} \Leftrightarrow \mathrm{H}_{2} \mathrm{CO}_{3}$ 

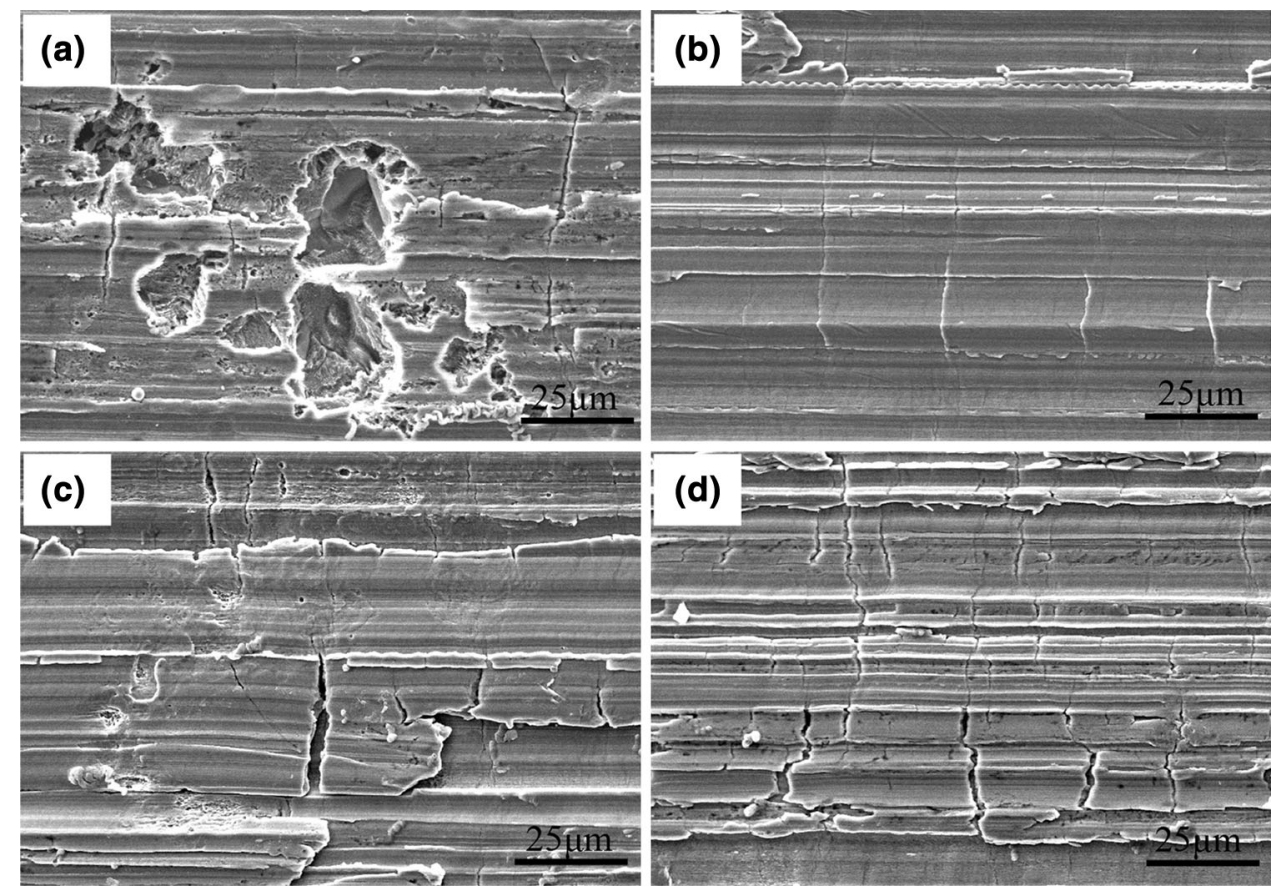

Fig. 7 SEM morphology of U-bent specimens of P110 steel under various $\mathrm{H}_{2} \mathrm{~S}$ partial pressures: (a) $P_{\mathrm{H}_{2} \mathrm{~S}}=0 \mathrm{MPa},\left(\right.$ b) $P_{\mathrm{H}_{2} \mathrm{~S}}=0.1 \mathrm{MPa}$, (c) $P_{\mathrm{H}_{2} \mathrm{~S}}=0.2 \mathrm{MPa}$, and (d) $P_{\mathrm{H}_{2} \mathrm{~S}}=0.3 \mathrm{MPa}$. All of the test solutions contained $1000 \mathrm{ppm}$ corrosion inhibitor
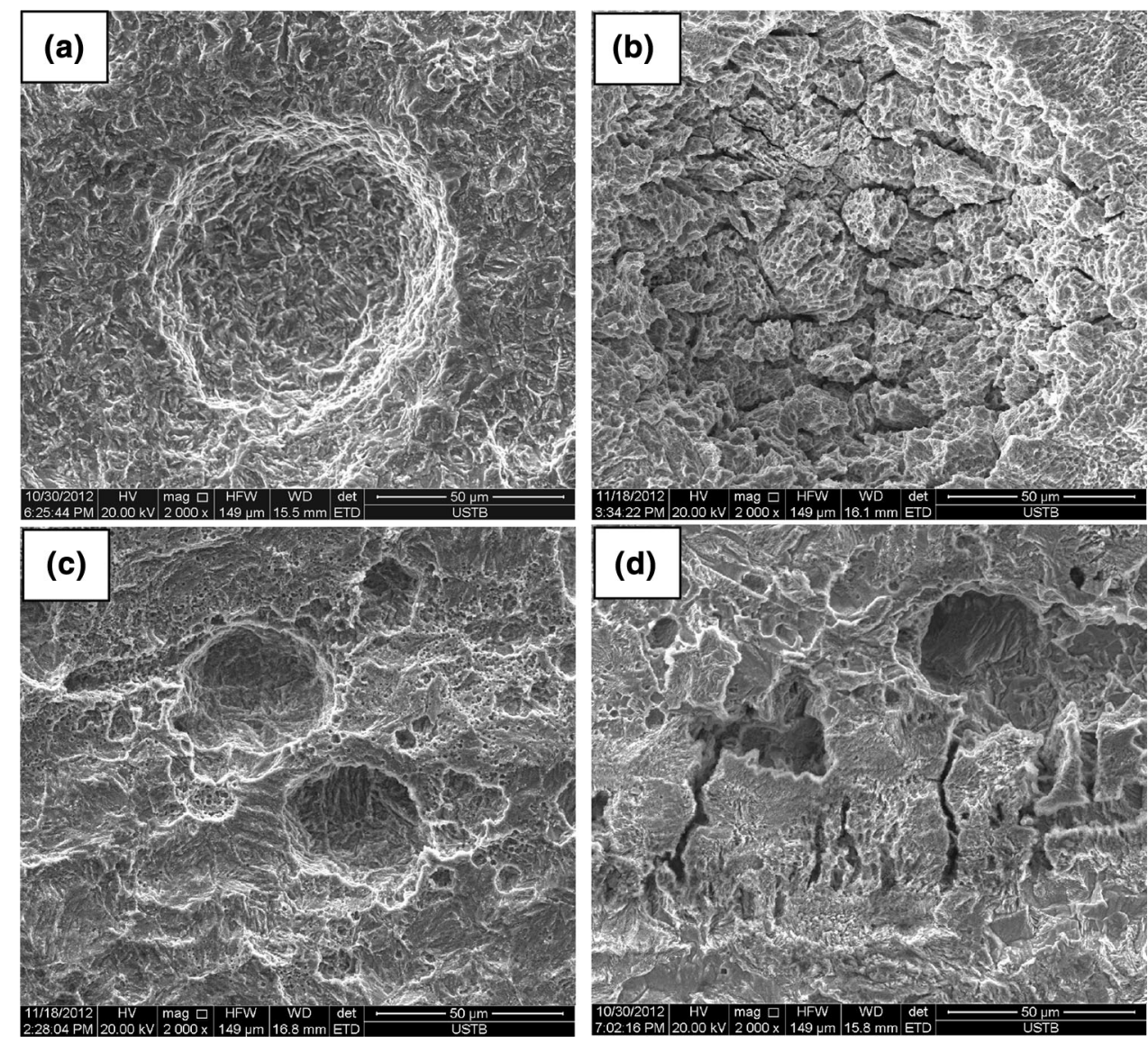

Fig. 8 SEM morphology of U-bent specimens: (a) $13 \mathrm{Cr}$ steel, $\mathrm{PCO}_{2}=4 \mathrm{MPa}$, without inhibitor; (b) $13 \mathrm{Cr}$ steel, $P_{\mathrm{H}_{2} \mathrm{~S}}=0.2 \mathrm{MPa}, \mathrm{PCO} 2=4$ $\mathrm{MPa}$, without inhibitor; (c) P110 steel, $\mathrm{PCO}_{2}=4 \mathrm{MPa}$, without inhibitor; and (d) P110 steel, $P_{\mathrm{H}_{2} \mathrm{~S}}=0.2 \mathrm{MPa}, \mathrm{PCO}_{2}=4 \mathrm{MPa}$, without inhibitor 


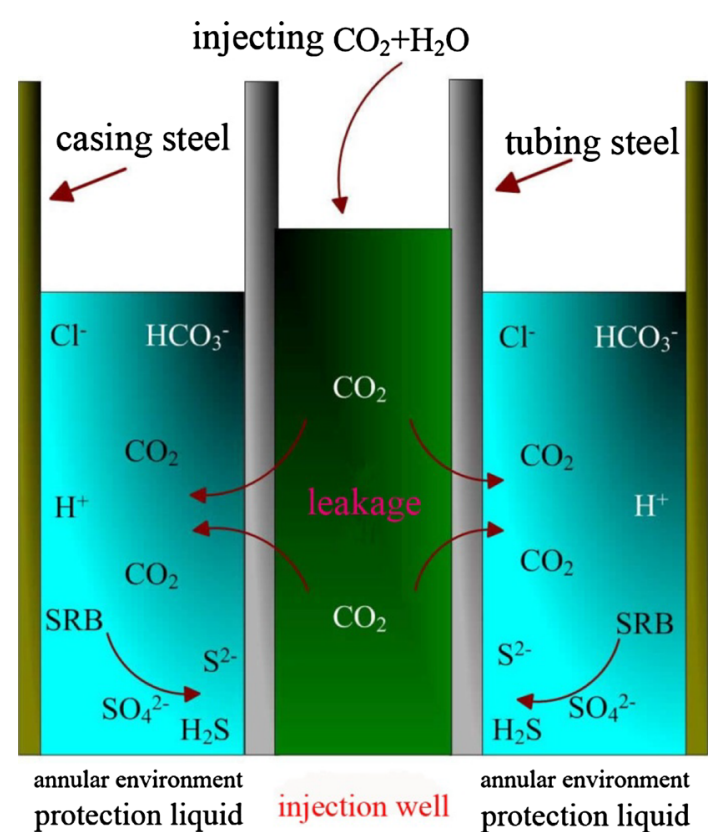

Fig. 9 Mechanism of the annular environment between tubing and casing steels

$\mathrm{H}_{2} \mathrm{CO}_{3} \Leftrightarrow \mathrm{H}^{+}+\mathrm{HCO}_{3}^{-}$

$\mathrm{HCO}_{3}^{-} \Leftrightarrow \mathrm{H}^{+}+\mathrm{CO}_{3}^{2-}$

The chemical dissociation of $\mathrm{CO}_{2}$ behaves similar to a weak acid and decreases the solution $\mathrm{pH}$ (the solution $\mathrm{pH}$ was $\sim 4$ ). This reaction accelerates the dissolution of steel during the anodic process, and the hydrogen evolution reaction in the cathodic process occurs as follows:

$\mathrm{Fe} \rightarrow \mathrm{Fe}^{2+}+2 \mathrm{e}$

$\mathrm{H}^{+}+\mathrm{e} \rightarrow \mathrm{H}$

Promotion of the cathodic hydrogen evolution process will increase the susceptibility of the tubular steel toward SCC because hydrogen atoms generated in the cathodic process could penetrate into the steel substrate.

The annular environment between the tubing steel and the casing steel is full of protection liquids. This stationary, enclosed, de-aerated environment should not contain $\mathrm{H}_{2} \mathrm{~S}$. However, our investigation on the solution medium extracted from the actual annular environment showed that the protective liquid contains a high concentration of $\mathrm{H}_{2} \mathrm{~S}$. Thus, the outer face of the tubing steel suffered from sulfate-reducing bacteria (SRB) corrosion. SRBs are anaerobic bacteria that reduce sulfate to sulfide. The presence of SRBs in the annular environment can consume sulfate radicals though cathodic depolarization, thereby converting sulfate to sulfide and promoting $\mathrm{H}_{2} \mathrm{~S}$ formation in an acid environment (Ref 22, 23):

$8 \mathrm{H}+\mathrm{SO}_{4}^{2-} \rightarrow \mathrm{S}^{2-}+4 \mathrm{H}_{2} \mathrm{O}$

$2 \mathrm{H}^{+}+\mathrm{S}^{2-} \rightarrow \mathrm{H}_{2} \mathrm{~S}$

The synergistic effects of leakage and presence of SRB promote the formation of a complex annular environment in
$\mathrm{CO}_{2}$ injection wells featuring low temperature, high pressure $\mathrm{CO}_{2} / \mathrm{H}_{2} \mathrm{~S}$, and low $\mathrm{pH}(\sim 4)$, as shown in Fig. 9.

\subsection{Effect of $\mathrm{H}_{2} \mathrm{~S}$ on Corrosion Behavior of Tubular Steel}

In a high-pressure $\mathrm{CO}_{2} / \mathrm{H}_{2} \mathrm{~S}$ environment, a significant difference exists between the effects of varying $P_{\mathrm{H}_{2} \mathrm{~S}}$ on the corrosion behaviors of tubular steels (Ref 24, 25). Pots et al. (Ref 26) claimed that the effects of $\mathrm{H}_{2} \mathrm{~S}$ on the corrosion behavior of steel in a $\mathrm{CO}_{2} / \mathrm{H}_{2} \mathrm{~S}$ environment depend on the $\mathrm{CO}_{2} / \mathrm{H}_{2} \mathrm{~S}$ ratio, which determines the nature of the scales and the corrosion mechanism. Although no specific critical $\mathrm{H}_{2} \mathrm{~S}$ concentration provides inhibition, the inhibitory effect may be related to the formation of a corrosion product film (Ref 15, 27). Choi (Ref 28) suggested that the precipitation of an iron sulfide and iron carbonate film is possible in acidic solutions $(\mathrm{pH}=3$ or 4$)$ because of local supersaturation in regions immediately above the steel surface. Corrosion product films form on the steel surface during the corrosion of the steel under a $\mathrm{CO}_{2} / \mathrm{H}_{2} \mathrm{~S}$ environment:

$\mathrm{Fe}^{2+}+\mathrm{CO}_{3}^{2-} \Leftrightarrow \mathrm{FeCO}_{3}$

$\mathrm{Fe}^{2+}+\mathrm{HS}^{-} \Leftrightarrow \mathrm{FeS}+\mathrm{H}^{+}$

During sweet corrosion, the corrosion product film is composed of $\mathrm{FeCO}_{3}$, which is a typical product of $\mathrm{CO}_{2}$ corrosion. However, with increases in the partial pressure ratio of $\mathrm{H}_{2} \mathrm{~S} / \mathrm{CO}_{2}$, the corrosion process gradually switches to $\mathrm{H}_{2} \mathrm{~S}$ and $\mathrm{CO}_{2}$ mix control, and the corrosion product film of $\mathrm{Fe}_{x} \mathrm{~S}$ is dominant under these conditions ( $\operatorname{Ref} 15)$.

In $13 \mathrm{Cr}$ stainless steel, $\mathrm{CO}_{2}$ corrosion dominates the corrosion process in conditions without $\mathrm{H}_{2} \mathrm{~S}$, and a layer of passive corrosion product film consisting of $\mathrm{Cr}(\mathrm{OH})_{3}$ and $\mathrm{FeCO}_{3}$ covers the steel surface (Ref 15 ). However, this layer of corrosion product film is not tightly adhered to the matrix and can be easily removed from the steel surface without the protection of the inhibitor. Some particles, such as carbides, act as cathodic sites, while the rest of the metal acts as an anode, and then many micro galvanic cells were formed (Ref 14). These heterogeneities sites disrupt the corrosion product film, such that severe pitting occurs without the inhibitor, as shown in Fig. 8(a) and (b). As the inhibitor is added to the solution medium, the metal matrix becomes well protected under the combined effects of the corrosion product film and the inhibitor. Thus, uniform corrosion with no cracks is observed in Fig. 6(a). In the presence of $\mathrm{H}_{2} \mathrm{~S}$, chemically dissociated ions, such as $\mathrm{HS}^{-}$and $\mathrm{S}^{2-}$, from the additional $\mathrm{H}_{2} \mathrm{~S}$ are strongly adsorbed on the surface of the steel. On one hand, these HS $^{-}$ and $\mathrm{S}^{2-}$ ions react with the passive film to form soluble corrosion products that promote the dissolution of the original passivity film. On the other hand, the $\mathrm{FeS}_{x}$ film generated by the $\mathrm{S}^{x-}$ and $\mathrm{Fe}^{2+}$ cannot protect the matrix since this $\mathrm{Fe}_{x} \mathrm{~S}$ film competes with the inhibitor covering the surface of steel (Ref 29-31). Thus, the passive surface film is severely damaged, which would explain why the polarization resistance $R_{\mathrm{p}}$ significantly decreases, as shown in Fig. 5(a). The part of the matrix without film or inhibitor protection will come into contact with the corrosive medium directly and become greatly corroded.

A layer of thin corrosion product film $\mathrm{FeCO}_{3}$ covers the P110 steel surface under $\mathrm{CO}_{2}$ corrosion. The severe pitting shown in Fig. 7(a) occurs during sweet corrosion because of the uneven distribution of the corrosion product film formed on 
the surface of the steel (Ref 14). During sour corrosion, the presence of $\mathrm{H}_{2} \mathrm{~S}$ dissociates in solution and facilitates the formation of a layer of $\mathrm{Fe}_{x} \mathrm{~S}$, which is more compact than the $\mathrm{FeCO}_{3}$ film and inhibits ion migration (Ref 2). Compared with sweet corrosion, $i_{\text {corr }}$ greatly decreases during sour corrosion because of the protection endowed by the $\mathrm{Fe}_{x} \mathrm{~S}$ film, which is reflected by the significantly increased $R_{\mathrm{p}}$ shown in Fig. 5(b). In contrast to the $13 \mathrm{Cr}$ stainless steel, the layer of $\mathrm{Fe}_{x} \mathrm{~S}$ film on the P100 steel does not compete with the inhibitor, and the matrix is well protected under the combined effects of the corrosion product film and the inhibitor. The different performances of the corrosion product film $\mathrm{Fe}_{x} \mathrm{~S}$ and the inhibitor cause $13 \mathrm{Cr}$ stainless steel and P110 steel to exhibit different corrosion behaviors in a sweet corrosion environment, i.e., the presence of $\mathrm{H}_{2} \mathrm{~S}$ accelerates the corrosion of $13 \mathrm{Cr}$ stainless steel but inhibits the corrosion of P110 steel.

The reduction of hydrogen ions is one of the main cathodic reduction reactions ( $\mathrm{Ref} 3-5$ ) in a solution of $\mathrm{pH} 4$. Hydrogen atoms generated from the cathodic process can penetrate into the steel matrix, which results in hydrogen-induced cracking (HIC) and contributes to the increased HIC susceptibility of steels. Thus, $\mathrm{SSCC}$ of the steels in a $\mathrm{CO}_{2} / \mathrm{H}_{2} \mathrm{~S}$ environment may be expected to be based on hydrogen, i.e., HIC. As shown in Figs. 6 and 7, for the $13 \mathrm{Cr}$ stainless steel surface shows no cracks during sweet corrosion, whereas the P110 steel surface exhibits several small cracks. These cracks reveal that P110 steel has higher susceptibility toward SSCC than $13 \mathrm{Cr}$ stainless steel in a high-pressure $\mathrm{CO}_{2}$ environment. SSCC cracks prevail under conditions with $\mathrm{H}_{2} \mathrm{~S}$, and the $13 \mathrm{Cr}$ stainless steel specimen fails under 0.2 and $0.3 \mathrm{MPa} \mathrm{H}_{2} \mathrm{~S}$. This result is attributed to high-pressure $\mathrm{H}_{2} \mathrm{~S}$ enhancing hydrogen ingress into the steel as well as HIC susceptibility, which is related to the increase in absorbed hydrogen content with increasing partial pressure of $\mathrm{H}_{2} \mathrm{~S}$ (Ref 25). The regularity of change in morphology (SSCC susceptibility) of the $13 \mathrm{Cr}$ stainless steel, as revealed by the immersion test, is consistent with that observed in the electrochemical test results $\left(i_{\text {pass }}\right)$. Both SSCC susceptibility and $i_{\text {pass }}$ were promoted by increasing $P_{\mathrm{H}_{2} \mathrm{~S}}$. For P110 carbon steel, however, the increase in SSCC susceptibility seems to be in conflict with the decrease in $i_{\text {corr }}$ as the $P_{\mathrm{H}_{2} \mathrm{~S}}$ increases from $\mathrm{H}_{2} \mathrm{~S}$-free to $0.3 \mathrm{MPa}$. As previously stated, the decrease in $i_{\text {corr }}$ may be attributed to the $\mathrm{FeS}_{x}$ film covering the steel surface; this layer of film provides protection to the steel. However, hydrogen atoms can still penetrate into the matrix because of their size, regardless of the presence or absence of a film layer. As the $\mathrm{H}_{2} \mathrm{~S}$ partial pressure increases from 0.1 to $0.3 \mathrm{MPa}$, more cracks appear on the specimen surface and susceptibility toward SSCC is enhanced with increasing $P_{\mathrm{H}_{2} \mathrm{~S}}$.

Overall, $13 \mathrm{Cr}$ stainless steel exhibited general corrosion while the P110 steel exhibited severe pitting under a highpressure $\mathrm{CO}_{2}$ environment. Such results may be due to differences in the protective performance of corrosion product scales on each surface. The presence of $\mathrm{H}_{2} \mathrm{~S}$ in $\mathrm{CO}_{2}$-containing environments can promote corrosion risk by facilitating corrosion in the $13 \mathrm{Cr}$ steel (increase $i_{\text {pass }}$ ) at a rate greater than that induced by pure $\mathrm{CO}_{2}$ corrosion. By contrast, the corrosion risk of P110 (decrease $i_{\text {corr }}$ ) can be decreased by preferentially forming a layer of $\mathrm{FeS}_{x}$ on the film surface; this type of film is more compact than $\mathrm{FeCO}_{3} \cdot \mathrm{H}_{2} \mathrm{~S}$ also increases SSCC risk by promoting hydrogen atom ingress into the substrate in for $13 \mathrm{Cr}$ stainless steel and P110 steel. Development of SSCC is of particular concern because it degrades steel and results in cracking.

\section{Conclusions}

The results of this study suggest that $13 \mathrm{Cr}$ stainless steel and P110 steel exhibit different corrosion behaviors and susceptibility toward SSCC under a simulated acidic annular environment with low temperature and $\mathrm{H}_{2} \mathrm{~S} / \mathrm{CO}_{2}$. In a solution of $4 \mathrm{MPa} \mathrm{CO}_{2}, 13 \mathrm{Cr}$ stainless steel exhibited general corrosion whereas P110 steel exhibited severe pitting. P110 steel showed higher susceptibility toward SSCC than $13 \mathrm{Cr}$ stainless steel under the experimental condition. Compared with sweet corrosion, additional $\mathrm{H}_{2} \mathrm{~S}$ accelerated the corrosion of $13 \mathrm{Cr}$ stainless steel but decreased the corrosion of P110 steel. The susceptibility of both $13 \mathrm{Cr}$ and P110 toward SSCC was significantly promoted in the presence of $\mathrm{H}_{2} \mathrm{~S}$. $13 \mathrm{Cr}$ showed higher susceptibility toward SSCC than P110 steel in a $\mathrm{H}_{2} \mathrm{~S}$ / $\mathrm{CO}_{2}$ environment. Moreover, a higher $\mathrm{H}_{2} \mathrm{~S}$ partial pressure in the solution allowed more hydrogen atoms to penetrate into the matrix, thereby increasing SSCC susceptibility.

\section{Acknowledgments}

This work was supported by the National Key Technology Research and Development Program of the Ministry of Science and Technology of China (No. 2011BAK06B01-01) and National Natural Science Foundation of China (No. 51131001).

\section{Open Access}

This article is distributed under the terms of the Creative Commons Attribution License which permits any use, distribution, and reproduction in any medium, provided the original author(s) and the source are credited.

\section{References}

1. R.A. Carneiro, R.C. Ratnapuli, and V.F.C. Lins, The Influence of Chemical Composition and Microstructure of API, Linepipe Steels on Hydrogen Induced Cracking and Sulfide Stress Corrosion Cracking, Mater. Sci. Eng. A, 2003, 357(1-2), p 104

2. W.F. Li, Y.J. Zhou, and Y. Xue, Corrosion Behavior of 110 S Tube Steel in Environments of High $\mathrm{H}_{2} \mathrm{~S}$ and $\mathrm{CO}_{2}$ Content, J. Iron. Steel Res. Int., 2012, 19(12), p 59

3. T. Omura, K. Kobayashi, and M. Ueda, SSC Resistance of High Strength Low Alloy Steel OCTG in High Pressure $\mathrm{H}_{2} \mathrm{~S}$ Environment, NACE, Atlanta, GA, 2009, Corrosion/2009, Paper No. 09102

4. S. Punpruk, Y. Gunaltun, and S. Daopiset, Sulphide Stress Cracking (SSC) Resistance of $13 \% \mathrm{Cr}$ and Super $13 \% \mathrm{Cr}$ Stainless Steels Below pH 3.5 in $\mathrm{H}_{2} \mathrm{~S}$ Environment, NACE, Atlanta, GA, 2009, Corrosion/ 2009, Paper No. 09298

5. T. Hara and H. Asahi, Conditions Under Which Cracks Occur in Modified 13\% Chromium Steel in Wet Hydrogen Sulfide Environments, Corrosion, 2000, 56(5), p 533

6. X.H. Zhao, Y. Han, Z.Q. Bai, and B. Wei, The Experiment Research of Corrosion Behavior About Ni-based Alloys in Stimulant Solution Containing $\mathrm{H}_{2} \mathrm{~S} / \mathrm{CO}_{2}$, Electrochim. Acta, 2011, 56, p 7725

7. S. Nesic, Key Issues Related to Modeling of Internal Corrosion of Oil and Gas Pipelines-A Review, Corros. Sci., 2007, 49(12), p 4308

8. H.V. Wang, and K. Allan, Internal Pipeline Corrosion Study on the Changes from Oil to Gas production, Trinidad and Tobago Energy Resources Conference, 2010, Port of Spain, Trinidad. Society of Petroleum Engineers

9. J. McKennis, N. Bae, M. Kimura, K. Shimamoto, and H.D. Sato, A New Chemical Mechanistic Postulate Regarding Annular Environmentally Assisted Cracking (AEAC) - Importance of Cations and Key Contaminants in Packer Fluids in Cracking of Martensitic Stainless 
Steel, NACE, New Orleans LA, 2008, Corrosion/2008, Paper No. 08483

10. J.S. McKennis, N. Bae, E.J. Termine, K. Shimamoto, and M. Kimura, Chemistry and Mechanisms of Completion/Packer Fluids: Annular Environmentally Assisted Cracking (AEAC) of Martensitic Stainless Steel Tubing: Misconceptions Regarding the Chemical Role of Completion/Packer Fluids, SPE International Symposium on Oilfield Chemistry, The Woodlands. TX, 2009

11. J. McKennis, N. Sook-Bae, E.J. Termine, K. Shimamoto, and M. Kimura, Misconceptions Regarding the Chemical Role of Completion/ Packer Fluids in Annular Environmentally Assisted Cracking of Martensitic Stainless Steel Tubing, SPE, 2010, 15(4), p 1104

12. J.S. McKennis, N. Bae, and E.J. Termine, Carbon Dioxide Corrosion When Least Expected: Importance of Carbonate Chemistry in Stress Corrosion Cracking on the External Surfaces of Martensitic StainlessSteel Production Tubing and Low-Alloy Carbon Steel Pipeline. SPE Annual Technical Conference and Exhibition, Florence, Italy, 2010

13. API Spec 5CT-2005. Specification for Casing and Tubing, API, 2005

14. Y.D. Cai, P.C. Guo, D.P. Liu, S.Y. Chen, and J.L. Liu, Comparative Study on $\mathrm{CO}_{2}$ Corrosion Behavior of N80, P110, X52 and 13Cr Pipe Lines in Simulated Stratum Water, Sci. China, 2010, 53(9), p 2342

15. C.Q. Ren, D.X. Liu, Z.Q. Bai, and T.H. Li, Corrosion Behavior of Oil Tube Steel in Simulant Solution with Hydrogen Sulfide and Carbon Dioxide, Mater. Chem. Phys., 2005, 93(2-3), p 305

16. M.E. Olvera-Martinez, J. Mendoza-Flores, F.J. Rodriguez-Gomez, M.E. Palomar-Pardave, and J. Genesca, Effects of turbulent flow on the corrosion inhibition properties of 2-mercaptobenz imidazole, Mater. Corros., 2013, 64(6), p 522

17. L.M. Rivera-Grau, M. Casales, and I. Regla, $\mathrm{H}_{2} \mathrm{~S}$ Corrosion Inhibition of Carbon Steel by a Coconut-Modified Imidazoline, Int. J. Electrochem. Sci., 2012, 7, p 12391

18. Z.Y. Liu, C.F. Dong, X.G. Li, Q. Zhi, and Y.F. Cheng, Stress Corrosion Cracking of 2205 Duplex Stainless Steel in $\mathrm{H}_{2} \mathrm{~S}_{-} \mathrm{CO}_{2}$ Environment, $J$. Mater. Sci., 2009, 44(16), p 4228

19. G.A. Zhang, Y. Zeng, X.P. Guo, F. Jiang, D.Y. Shi, and Z.Y. Chen, Electrochemical Corrosion Behavior of Carbon Steel Under Dynamic High Pressure $\mathrm{H}_{2} \mathrm{~S} / \mathrm{CO}_{2}$ Environment, Corros. Sci., 2012, 65, p 37
20. J. Zhang, Z.L. Wang, Z.M. Wang, and X. Han, Chemical Analysis of the Initial Corrosion Layer on Pipeline Steels in Simulated $\mathrm{CO}_{2}-$ Enhanced Oil Recovery Brines, Corros. Sci., 2012, 65, p 397

21. M. Nobakht, S. Moghadam, and Y.G. Gu, Effects of Viscous and Capillary Forces on $\mathrm{CO}_{2}$ Enhanced Oil Recovery under Reservoir Conditions, Energy Fuel, 2007, 21(6), p 3469

22. F.M. Alabbas, C. Williamson, S.M. Bhola, J.R. Spear, D.L. Olson, B. Mishra, and A.E. Kakpovbia, Influence of Sulfate Reducing Bacterial Biofilm on Corrosion Behavior of Low-Alloy, High-Strength Steel (API-5L X80), Int. Biodeterioration Biodegrad., 2013, 78, p 34

23. F. Kuang, J. Wang, L. Yan, and D. Zhang, Effects of Sulfate-Reducing Bacteria on the Corrosion Behavior of Carbon Steel, Electrochim. Acta, 2007, 52(20), p 6084

24. Z.F. Yin, W.Z. Zhao, Z.Q. Bai, Y.R. Feng, and W.J. Zhou, Corrosion Behavior of SM 80SS Tube Steel in Stimulant Solution Containing $\mathrm{H}_{2} \mathrm{~S}$ and $\mathrm{CO}_{2}$, Electrochim. Acta, 2008, 53(10), p 3690

25. C.S. Zhou, S.Q. Zheng, C.F. Chen, and G.W. Lu, The Effect of the Partial Pressure of $\mathrm{H}_{2} \mathrm{~S}$ on the Permeation of Hydrogen in Low Carbon Pipeline Steel, Corros. Sci., 2013, 67, p 184

26. B.F.M. Pots, R.C. John, I.J. Rippon, M.J.J.S. Thomas, S.D. Kapusta, M.M. Girgis, T. Whitham, Improvements on de Waard-Milliams Corrosion Prediction and Application to Corrosion Management, NACE Corrosion/2002, Denver, CO, 7-11 April, 2002, Paper No. 235, p 1

27. H.Y. Ma, X.L. Cheng, G.Q. Li, and S.H. Chen, The Influence of Hydrogen Sulfide on Corrosion of Iron Under Different Conditions, Corros. Sci., 2000, 42, p 1669

28. Y.S. Choi, S. Nesic, and S. Ling, Effect of $\mathrm{H}_{2} \mathrm{~S}$ on the $\mathrm{CO}_{2}$ Corrosion of Carbon Steel in Acidic Solutions, Electrochim. Acta, 2011, 56, p 1752

29. D.A. Lopez, T. Perez, and S.N. Simison, The Influence of Microstructure and Chemical Composition of Carbon and Low Alloy Steels in $\mathrm{CO}_{2}$ Corrosion. A State-of-the-art Appraisal, Mater. Des., 2003, 24, p 561

30. E. Gulbrandsen, R. Nyborg, T. Løland, and K. Nisancioglu. Effect of Steel Microstructure and Composition on Inhibition of $\mathrm{CO}_{2}$ Corrosion. NACE Houston TX, 2000, Corrosion/2000, Paper No. 00023

31. L.D. Paolinelli, T. Perez, and S.N. Simison, The Effect of Pre-corrosion and Steel Microstructure on Inhibitor Performance in $\mathrm{CO}_{2}$ Corrosion, Corros. Sci., 2008, 50, p 2456 